\title{
Comparative analysis of human omental milky spots between the patients with colon cancer and the control group
}

\author{
Havrlentova $\mathrm{L}^{1,2}$, Faistova $\mathrm{H}^{3,4,5}$, Mazur $\mathrm{M}^{1}$, Ziak $\mathrm{D}^{3,5}$, Polak $\mathrm{S}^{2}$ \\ Surgical Department, Vitkovice Hospital, Ostrava, Czech Republic. lucia.havrlentova@seznam.cz
}

\begin{abstract}
AIM: Morphological description of milky spots (MSs) in the human greater omentum.

METHOD: Samples of the greater omentum collected during surgical procedures were subjected to further histological analysis. Two groups of patients were studied. Group A consisted of patients with colon cancer and peritonitis (stimulated MSs), group B consisted of patients without colon cancer and without peritonitis (unstimulated MSs). In the research, we focused on the cellular composition and differences between stimulated and unstimulated MSs.

RESULTS: MSs detected in the study were predominantly oval (67\%), round (12\%) or irregular in shape $(21$ $\%)$. The average number of immune cells found in one milky spot (MS) in the group A was 454 (209-694), consisted of T cells in $44.7 \%(27-55 \%)$, B cells in $26.8 \%(16-34 \%)$, macrophages in $18.3 \%(12-27 \%)$ and other immune cells in $10.2 \%(6-18 \%)$. The average number of immune cells found in one MS in the group B was $58(42-100 \%)$, consisted of T cells in $21.1 \%(16-22 \%)$, B cells in $18.7 \%(13-22 \%)$, macrophages in $46.9 \%(33-60 \%)$ and other immune cells in $13.3 \%(1-22 \%)$. The average size of MSs in the group A was significantly higher than in the group B: $768 \mu \mathrm{m}(313-1075)$ to $293 \mu \mathrm{m}(197-421)$. The results showed that there were significant differences in terms of strong predominance of macrophages in unstimulated milky spots and strong predominance of T cells in stimulated milky spots.

CONCLUSION: MSs are specific immune active lymphatic structures on the greater omentum. They play a key role in defense mechanism, especially in peritonitis. Their function is not completely clear in cancer, some authors suggest they might play a significant role in omental metastasis. Further analysing of the morphology and cells interactions of MSs is needed (Tab. 2, Fig. 6, Ref. 20). Text in PDF www.elis.sk.

KEY WORDS: milky spots, peritonitis, colon cancer, omentum.
\end{abstract}

\section{Introduction}

Milky spots were described in 1863 by Recklinghausen as white spots in the omentum of young rabbits (1). 10 years later they were named as "taches laiteuses" by Ranvier (2). MSs in the human omentum were first described by Seifert (3). MSs develop as specific structures in the greater omentum between the 20th and 35th week of gestation. True milky spots in terms of cell size and cell number are present by the 35 th week of gestation. During childbirth, MSs are present as well-developed structures achieving their maximum number (30-40 MSs per $1 \mathrm{~cm}^{2}$ area of the greater omentum). Mature macrophages are the most common type of cells. B and T-cells represent less than $10 \%$ of the cell population (4). In adulthood, there are only $2 \mathrm{MSs}$ present per $1 \mathrm{~cm}^{2}$ of the greater

${ }^{1}$ Surgical Department, Vitkovice Hospital, Ostrava, Czech Republic, ${ }^{2}$ Institute of Histology and Embryology, Faculty of Medicine, Comenius University in Bratislava, Slovakia, ${ }^{3}$ CGB Laboratory, Ostrava, Czech Republic, ${ }^{4}$ University of Ostrava, Faculty of Medicine, Ostrava, Czech Republic, and ${ }^{5}$ Institute of Pathology, Univesity Hospital in Ostrava, Czech Republic

Address for correspondence: L. Havrlentova, MD, Surgical Department, Vitkovice Hospital, Ostrava, Czech Republic. omentum (5). The number of milky spots is highest in infancy and gradually decreased with age (6). The origins of lymphatics start in milky spots (5). Borisov described them as blind-beginning lymphatic capillaries located on the surface of the milky spots close to the mesothelial cells, which drain into the efferent lymphatic vessels (7). Milky spots are very small unencapsulated omental structures covered by mesothelial cells. They are in close contact with the peritoneal cavity and supported by blood and lymphatic vessels. MSs primarily consist of macrophages, lymphocytes and other immune cells (8). Milky spots take part in the clearance of particles, bacteria, and tumour cells from the abdominal cavity (9). The capillaries of milky spots are fenestrated in contrast to other capillaries of the omentum, which lack these special type of endothelium (10). According to Shimotsuma, the average number of immune cells in one MS is 600 (11). By contrast, Liu indicates the median number of cells 141 (12). The others approach describes milky spots as reactive structures, their classification varying from haematopoetic tissue to lymphoid organs (13). Some authors find milky spots as primary lymphoid organs (14), the others find them as secondary lymphoid organs (15). Liu et al. consider milky spots as the primary immune tissue (12). In the study, we focused and examined both stimulated and unstimulated milky spots. 
Tab. 1. Primary antibodies.

\begin{tabular}{lccc}
\hline Primary antibody & Clone & Dilution & Used for \\
\hline Monoclonal mouse antibody CD45/RB & 2B11+PD 7/26 & $1: 50$ & Leukocyte common antigen \\
Polyclonal rabbit antibody CD3 & - & $1: 50$ & T lymphocytes \\
Monoclonal mouse antibody CD20 & L26(ab9475) & $1: 50$ & B lymphocytes \\
Monoclonal mouse antibody CD68 & PG-N1 & $1: 500$ & Macrophages \\
Polyclonal mouse antibody S100 & - & $1: 100$ & Nerves \\
\hline
\end{tabular}

Tab. 2. Results and comparative analysis between groups.

\begin{tabular}{lcc}
\hline Parameter of milky spots & $\begin{array}{c}\text { Group A } \\
\text { (stimulated MSs) } \\
\text { Average (range) }\end{array}$ & $\begin{array}{c}\text { Group B } \\
\text { (unstimulated MSs) } \\
\text { Average (range) }\end{array}$ \\
\hline Number of immune cells & $454(209 \sim 694)$ & $58(42 \sim 100)$ \\
Size $(\mu \mathrm{m})$ & $768(313 \sim 1075)$ & $293(197 \sim 421)$ \\
T lymfocytes $(\%)$ & $44.7(27 \sim 55)$ & $21.1(16 \sim 22)$ \\
B Lymfocytes $(\%)$ & $26.8(16 \sim 34)$ & 0.0007 \\
Macrophages(\%) & $18.3(12 \sim 27)$ & 0.0068 \\
Other immune cells $(\%)$ & $10.2(6 \sim 18)$ & $46.9(33 \sim 60)$ \\
\hline
\end{tabular}

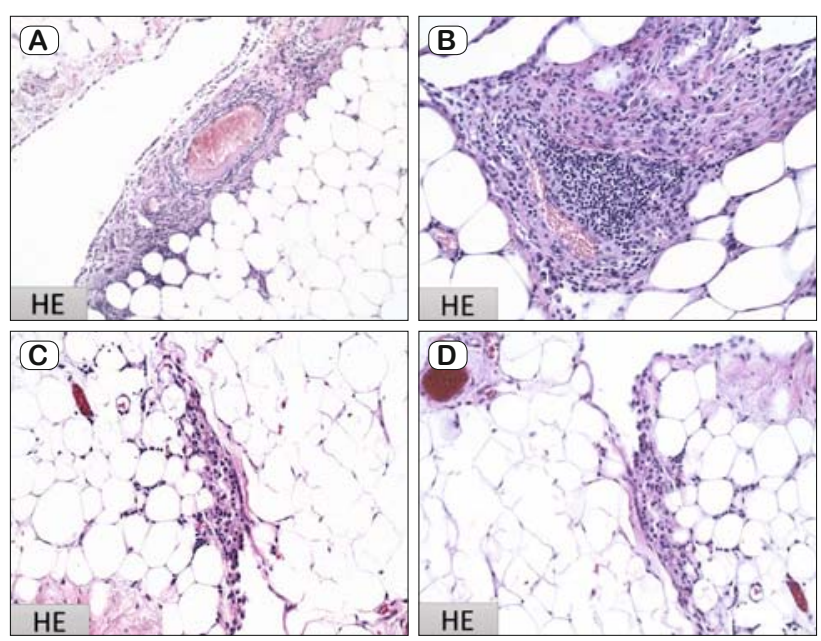

Fig. 1. Slides A and B represent MSs in omentum of stimulated patients where these larger vessels are common findings. MSs on $C$ and $D$ were found in unstimulated omentum. The differences in size as well as in cell number are obvious. Magn. x200.



Fig. 2. MS star in shape, located between adipocytes, without mesothelial cover; a nerve fascicle is well identifiable on slide stained hematoxylin-eosin and specific S100 protein antibody on the right. Mang. x200.

\section{Materials and methods}

The cellular composition of human omental milky spots was described on specimens (samples of the greater omentum), which were obtained after surgical procedures from 10 patients (Depart- ment of Surgery, Vitkovická Hospital, Ostrava, Czech Republic). The samples were analysed in CGB Laboratory in Ostrava. The study was approved by our hospital's ethnics committee. All patients agreed to participate in the study and signed the informed consent. The samples of the greater omentum collected during surgical procedures were divided into two groups and subjected to further detailed histological analysis. In the analysis, we have focused on cell morphology, number of cells, the cellular composition of MSs and differences between stimulated and unstimulated MSs. Group A $(n=5)$ comprised of patients with colon cancer stage T3-T4 (NxM0) and peritonitis (stimulated milky spots). Group B $(\mathrm{n}=5)$ comprised of patients without colon cancer and without peritonitis (unstimulated milky spots), electively operated for inguinal hernia. The differences in milky spots parameters between the two groups were also analysed. The data showed below concerning unstimulated MSs could present a reference design of cellular substance in human omental milky spots (since inflammation and cancer were absent in the investigated material). The tissue specimens were fixed in $10 \%$ buffered formalin for 24-48 hours. The number of tissue blocks per case was 4 . All the samples were paraffin embedded and 4-6 $\mu \mathrm{m}$ paraffin sections were stained using the haematoxylin and eosin method (HE). The 4-6 $\mu \mathrm{m}$ thick sections were retrieved from representative paraffin blocks ( $\mathrm{n}=$ 10) in all patients. Immunohistochemistry was performed in the automated tissue staining system Benchmark XT (Ventana Medical Systems, Inc., Tucson, AZ, USA) to focus on the cellular composition of MSs (Figs 3 and 4). To detect leucocytes, T-lymphocytes, B-lymphocytes and macrophages, primary antibodies, described in the Table 1, were applied. Positivity was manifested by brown colour contours of cytoplasmatic membrane. Positive controls were added for each stain. Cells count was conducted using the monoclonal antibody LCA (leukocyte common antigen), which marks all types of immune cells and allowed us to count cells directly. The slides were examined by a light microscopy (Olympus BX4540x, 100x, 200x or 400x magnification). Pictures were made with Olympus camera (U-TVO.5XC-3 - 200x magnification). Statistical analyses were performed in Microsoft Excel. The differences 



Fig. 3. MS of patient with colorectal carcinoma and peritonitis demonstrates characteristic composition of all immune cells (LCA), Tlymphocytes (CD3), B-lymphocytes (CD20) and macrophages (CD68). Magn. x200.

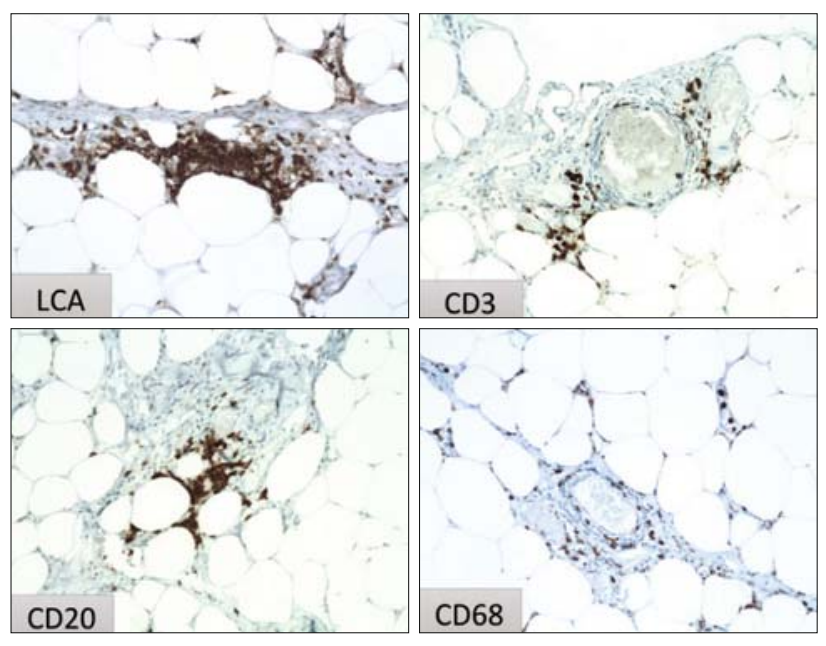

Fig. 4. Representative features of cellular constituets of MSs: all immune cells (LCA), T-lymphocytes (CD3), B-lymphocytes (CD20) and macrophages (CD68). Magn. x200.

between MSs in the Group A and the Group B were calculated by t-test and $p<0.05$ was considered statistically significant.

\section{Results}

MSs detected in the study were predominantly oval (67\%), round (12\%) or irregular (21\%) in shape. All milky spots were un-encapsulated. Most of them were covered by mesothelial cells (Fig. 1). In some MSs, we detected nerve fascicles (Fig. 2). The average number of MSs per unit area (per square centimetre) was 1.6 in unstimulated stage (group B), which corresponds to literature

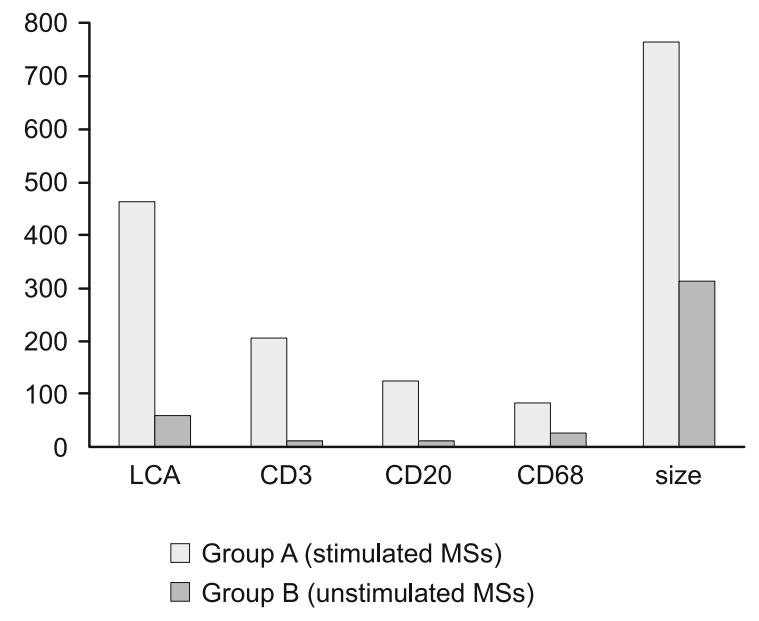

Fig. 5. Comparison of MS parameters.

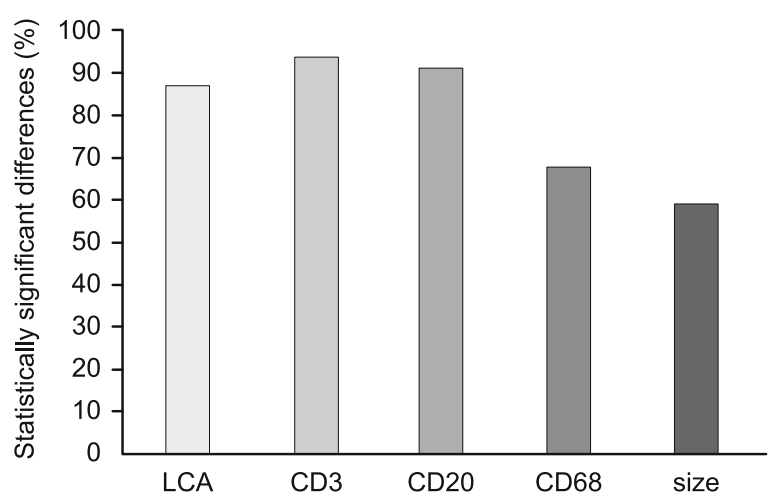

Fig. 6. Statistically significant differences. 
data (5). By comparison, the average number of stimulated MSs (group A) was 4.3 per unit area. Unfortunately, the average number of MSs in stimulated stage could not be compared with another source, because we did not find any data available in literature. The results of cells numbers were expressed as the average value and in the relevant range. Cellular constituents were expressed as the percentage using a decimal number. The corresponding range of the cells was also expressed as the percentage, but rounded to the nearest integer. The average number of immune cells found in one MS in the Group A (stimulated) was 454 (209 694). The cells consisted of $\mathrm{T}$ cells in $44.7 \%(27-55 \%)$, B cells in 26.8 $\%(16-34 \%)$, macrophages in $18.3 \%(12-27 \%)$, and other immune cells in $10.2 \%(6-18 \%)$. The average number of immune cells found in one MS in the Group B (unstimulated) was 58 (42 $\sim 100)$. They consisted of T cells in $21.1 \%(16-22 \%)$, B cells in $18.7 \%$ (13-22\%), macrophages in $46.9 \%$ (33-60\%), and other immune cells in $13.3 \%(1-22 \%)$. The differences between the MS in patients with and without peritonitis were considered statistically significant in terms of strong predominance of macrophages in unstimulated milky spots and strong predominance of T cells in stimulated milky spots (Fig. 5). The data also showed that the average number of cells in stimulated MSs was almost 10x higher than in unstimulated milky spots. We observed a positive correlation between the number of cells and size of milky spots. The average diameter of unstimulated MSs was $293 \mu \mathrm{m}$. The average diameter of stimulated MSs was $768 \mu \mathrm{m}$. The above data showed that the average diameter of stimulated MSs was almost 2.6x larger than the average diameter of unstimulated MS. The increase in size and cellular components of milky spots could be due to the inflow of cells from the blood and bone marrow caused by inflammation (16). We did not find any specific B and T-cells areas characteristic for secondary lymphoid organs. A comparative analysis of MS components between the group A and B is showed in the Table 2. Statistically significant differences are showed on the Figure 6.

\section{Discussion}

Milky spots represent the main immune system of the peritoneal cavity. They have a prominent role in peritoneal defense mechanisms (17). MSs are small sub-mesothelial lymphatic structures, essential for the maturation of macrophages, antibodies production, proliferation of $\mathrm{B}$ cells, peritoneal defense, and for all peritoneal inflammatory and immune processes (18). Some authors divide them into two categories: vascularized and nonvascularized. Vascularized MSs (supplied with blood vessels) are abundantly present in the omental fat band. Non-vascularized MSs are located particularly in the area of omental membrane (19). In our study, we did not find any non-vascularized MSs. Thus, it remains un-investigated whether the two groups of MSs play a different role or have functional differences. The data from our study indicated that milky spots in the human greater omentum were immune active structures and played an important role in peritoneal defence. According to some authors, MSs could serve as a gateway for, as well as a provider of peritoneal macrophages, when the intraabdominal status requires so (20). Stimulated milky spots promote an increase of microvascular permeability. Therefore, the cell migration increases across mesothelial cells into the peritoneal cavity and vice versa. The cellular migration from the milky spot to the peritoneal cavity is facilitated by the absence of a basal lamina and by intercellular gaps between mesothelial cells (10). The increase in size and number of cellular components of milky spots could be due to the inflow of cells from the blood and bone marrow caused by inflammation (16). The number of milky spots is the highest in infancy (during the first year of life) and gradually decreases with age. In the first year of life, the average number of MSs is approximately 19.6 per $1 \mathrm{~cm}^{2}$ of the greater omentum. In adult organism, on the contrary, the average number of MSs represent only 2 per $1 \mathrm{~cm}^{2}$ (5). These data correlate with our results. The number of milky spots in unstimulated stage in adult organism is 1.6 per $1 \mathrm{~cm}^{2}$. The results of our study also showed that the number of MSs in the stimulated adult organism is 4.3 per $1 \mathrm{~cm}^{2}$. The average number of MSs in a stimulated stage could not be compared with another source, because we did not find any data available in literature. According to Shimotsuma et al, the average number of cells in one MS is 600 (11). On the contrary, Liu et al. use the median as the primary parameter for the cell statistics, which is 141 (12). In our study, the average number of cells in unstimulated MS is 58 and the average number in stimulated MS represent 454. These findings also correspond to the published data. The data showed below in unstimulated MSs could present a reference design of cellular substance in human omental milky spots (since inflammation and cancer were absent in the material investigated). Our results further indicated that in the group B (unstimulated MSs), the most numerous number of cells was represented by macrophages $(46.9 \%)$, which form the basic component of non-specific (natural cellular) immunity. In the group A (stimulated MSs), the highest number of cells was represented by T lymphocytes (44.7\%). During cancer and peritonitis, the percentage of the cells changes to T lymphocytes as specific immune cells. The differences between the MSs in patients with and without peritonitis are considered statistically significant in terms of strong predominance of macrophages in unstimulated milky spots and strong predominance of $\mathrm{T}$ cells in stimulated milky spots. The average number of cells in stimulated MS is $10 \mathrm{x}$ higher and its size is $2.6 \mathrm{x}$ larger. We did not find any specific $\mathrm{B}$ and T-cells areas characteristic for secondary lymphoid organs. On the structural basis, our results in the group A correlate with the published work of Liu (12). On the other hand, morphological and immunohistochemical analyses in unstimulated milky spots mostly correspond with the work of Krist (20). We came to the conclusion that there is a potential for further studies of milky spots regarding subtypes resolution of $\mathrm{T}$ lymphocytes and macrophages (for their relationship to the anti-tumour immunity) and analysing extracellular matrix. The exact role of MSs is still not clear. However, MSs definitely play an important role in peritoneal infection and spreading of abdominal tumours (8). It can be assumed that the results of our morphological analysis of human omental milky spots could be a source of valuable information in the field of basic and applied research as well as in the field of clinical and experimental practices. 
$580-584$

\section{Conclusion}

Milky spots, either stimulated or unstimulated, are specific immune active vascularized structures. They play a key role in the peritoneal defence mechanism. In case of inflammation, the cell size as well as the cell number in MSs dramatically increases. Our results demonstrated that the average number of immune cells was almost 10x higher in stimulated MSs. Unstimulated MSs consisted predominantly of macrophages (46.9\%), which are essential components of non-specific (natural cellular) immunity. In stimulated MSs, the major cells were T lymphocytes (44.7\%) for the specific immunity. The increasing number of immune cells during inflammation is probably caused by immigration of cells. In the study, we did not find any specific B or T areas, typical for lymphoid organs. We came to the conclusion that MSs had an import role in the fight with peritoneal infection.

\section{References}

1. Recklinghausen FV. Uber Eiter und Bindesgewebs-korperchen. Vir Arch Pathol Anat 1863; 28: 157.

2. Ranvier L. Du développement et de l'accroissement des vaisseaux sanguins. Arch Physiol 1874; 1: 429.

3. Seifert E. Zur Biologie des menschlichen grossen Netzes. Arch Klin Chir 1921; 510-517.

4. Krist LF, Koenen H, Calame W, van der Harten JJ, van der Linden JC, Eestermans IL, Beelen RH. Ontogeny of milky spots in the human greater omentum: an immunochemical study. The Anatomical Record 1997; 249 (3): 399-404.

5. Shimotsuma M, Shields JW, Simpson-Morgan MW, Sakuyama A, Shirasu M, Hagiwara A, Takahashi T. Morpho-physiological function and role of omental milky spots as omentum-associated lymphoid tissue (OALT) in the peritoneal cavity. Lymphology 1993; 26 (2): 90-101.

6. Shimotsuma M, Kawata M, Hagiwara A, Takahashi T. Milky spots in the human greater omentum. Cells Tissues Organs 1989; 136 (3): 211-216.

7. Borisov AV. Lymphatic capillaries and blood vessels of milky spots in the human greater omentum. Federation proceedings. Translation supplement; selected translations from medical-related science 1963; 23: 150154.
8. Sacchi G, Di Paolo N, Venezia F, Rossi A, Nicolai GA, Garosi G. Possible role of milky spots in mesothelial transplantation. The International J Artif Organs 2007; 30 (6): 520-526.

9. Mebius RE. Lymphoid organs for peritoneal cavity immune response: milky spots. Immunity 2009; 30 (5): 670-672.

10. Cranshaw ML, Leak LV. Milky spots of the omentum: a source of peritoneal cells in the normal and stimulated animal. Arch Histol Cytol 1990; 53 (Suppl): 165-177.

11. Shimotsuma M, Takahashi T, Kawata M, Dux K. Cellular subsets of the milky spots in the human greater omentum. Cell Tissue Res 1991; 264 (3): 599-601.

12. Liu JY, Yuan JP, Geng XF, Qu AP, Li Y. Morphological study and comprehensive cellular constituents of milky spots in the human omentum. Internat J Clin Exp Pathol 2015; 8 (10): 12877.

13. Van Vugt E, Van Rijthoven EA, Kamperdijk EW, Beelen RH. Omental milky spots in the local immune response in the peritoneal cavity of rats. Anat Record 1996; 244 (2): 235-245.

14. Koten JW, Den Otter W. Are omental milky spots an intestinal thymus? Lancet 1991; 338 (8776): 1189-1190.

15. Rangel-Moreno J, Moyron-Quiroz JE, Carragher DM, Kusser K, Hartson L, Moquin A, Randall TD. Omental milky spots develop in the absence of lymphoid tissue-inducer cells and support $\mathrm{B}$ and $\mathrm{T}$ cell responses to peritoneal antigens. Immunity 2009; 30 (5): 731-743.

16. Kremli SM, Mamontov SG. Morphological features of milky spots of the rat omentum in inflammation. Biull Eks Biol Med 1990; 109 (6): 616-619.

17. Platell C, Cooper D, Papadimitriou JM, Hall JC. The omentum. World J Gastroenterol 2000; 6 (2): 169.

18. Garosi G, Di Paolo N. Recent advances in peritoneal morphology: the milky spots in peritoneal dialysis. Adv Perit Dialysis 2001; 17: 25-28.

19. Takemori N, Hirai K, Onodera R, Saito N, Namiki M. Light and electron microscopic study of omental milky spots in New Zealand black mice, with special reference to the extramedullary hematopoiesis. Anat Embryol 1994; 189 (3): 215-226.

20. Krist LF, Eestermans IL, Steenbergen JJ, Hoefsmit E, Cuesta MA, Meyer S, Beelen RH. Cellular composition of milky spots in the human greater omentum: an immunochemical and ultrastructural study. Anat Record 1995; 241 (2): 163-174. 